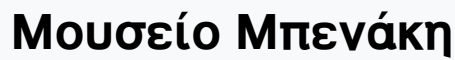

Tóp. 2 (2002)

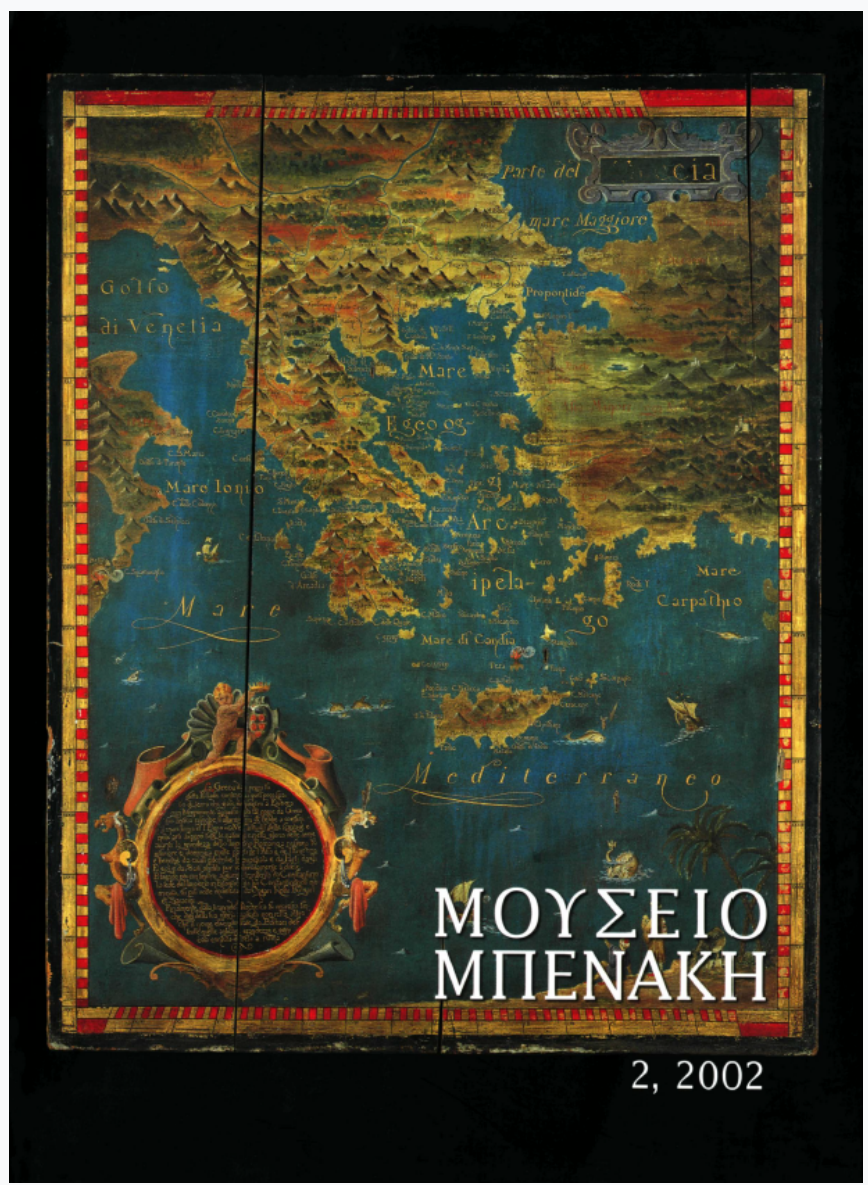

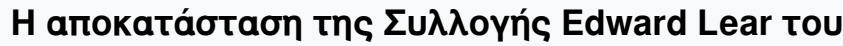

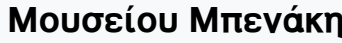

Fani-Maria Tsigakou

doi: $\underline{10.12681 / \text { benaki.18193 }}$

Copyright @ 2018, Fani-Maria Tsigakou

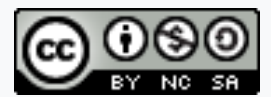

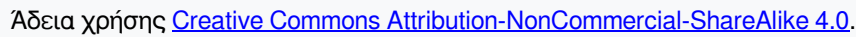

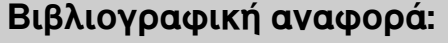

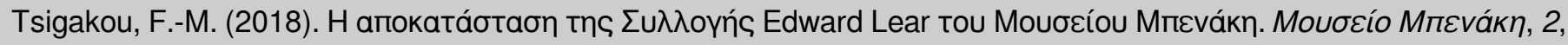
137-146. https://doi.org/10.12681/benaki.18193 


\section{Reassessing the Edward Lear Collection at the Benaki Museum}

MUSEUM COLLECTIONS have a personal history of their own: that is part of their appeal. To understand the history of the Benaki Museum's Edward Lear collection, and how it arrived at its present form, we must first unravel a convoluted plot in which Lear shares the leading role with a fellow Englishman whose name is totally unknown to any dictionary of art.

The Edward Lear collection comprises 182 works. Some are exhibited in the Museum, and the remainder are kept in the Department of Paintings, Prints and Drawings. Apart from a superb oil painting of Marathon (fig. 1), donated in 1997 by Stamos J. Fafalios, ${ }^{1}$-a good friend of the Museum-, in memory of his father, the collection consists of pencil and ink drawings and watercolours. Most of these were donated by Damianos Kyriazis in 1952-53, but some were acquired by Antonis Benakis, the founder of the Museum, while a small group from the house of Kyriazes' daughter, Mrs Maria Spentsa, came to the Museum only recently. The works date from 1838-39, 1848-49 and 1850-1863, and they include landscapes, views and impressions made during the artist's travels in Italy and Greece. ${ }^{2}$

Edward Lear (1812-1888) was the most prolific 19th century British travel writer and artist-traveller, and he recorded his visual experiences in hundreds of sketchbooks. ${ }^{3}$ He began his artistic career as an illustrator of natural history and zoology books, but after turning to landscape painting in 1835 he developed into one of the major figures of the 19th century British romantic school. ${ }^{4} \mathrm{He}$ first came to Greece in spring 1848 , and by the summer of the following year he had visited much of
Mainland Greece, as well as Albania and Macedonia: ${ }^{5}$ his tour of the Peloponnese and Attica in March and April 1849 forms the background to this article. One result of these visits was the publication in 1851 of an illustrated travel diary entitled Journals of a Landscape Painter in Albania etc. ${ }^{6}$

Between 1855 and 1864 he spent nearly every winter in Corfu, an island which became a favourite subject of his.? His sumptuous album of lithotints, Views in the Seven Ionian Islands (London 1863), is devoted to those islands, ${ }^{8}$ and he used Corfu as a base from which to record the Greek shores opposite. During a total of four years spent in Greece he undertook sketching expeditions throughout the length and breadth of the mainland from Mystras to Mount Athos, as well as to most of the islands, notably the Ionian islands and Crete, and this puts his work on a different level from the amateur efforts of most of the artist-travellers who visited Greece in the 19th century. Lear was a philhellene with a deep knowledge of Ancient Greece, and the quality, thematic variety and quantity of his output -approximately 3. 000 works in all- has made him recognised as the 19th century painter of the Greek landscape par excellence.

The records of the Damianos Kyriazes donation mention a portfolio of 110 drawings by Edward Lear, which I located when I was cataloguing the collection. A board portfolio $(60 \times 45 \mathrm{~cm})$, marked Collection of Drawings, Views of Greece etc, it contains 110 pencil and ink sketches on paper varying in size from $13.5 \mathrm{x}$ $22 \mathrm{~cm}$ to $28.5 \times 52 \mathrm{~cm}$. These contents, however, raised a whole host of questions in my mind, since little of 


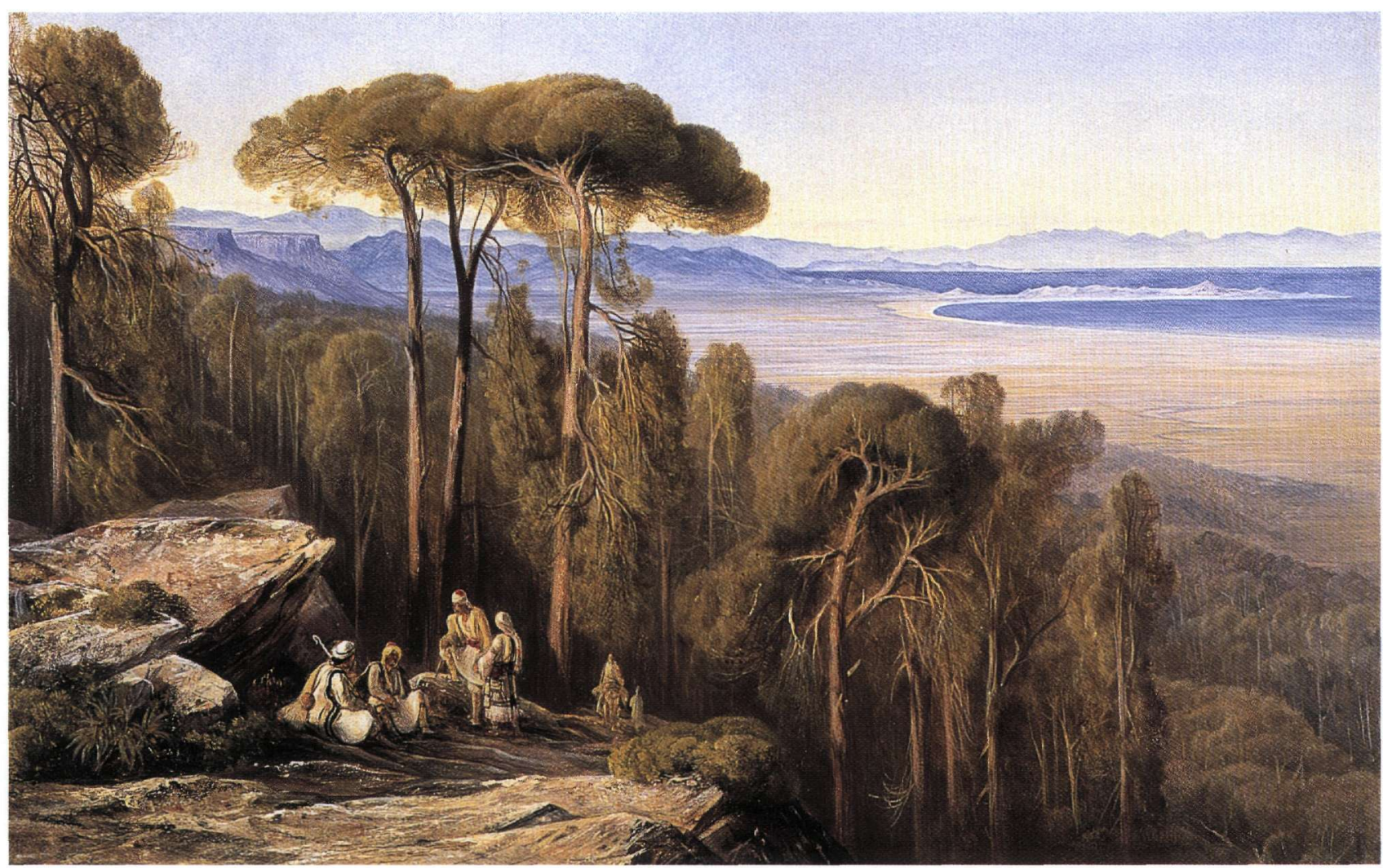

Fig. 1. E. Lear. View of Marathon, 1854. Oil on canvas, 33 x $53 \mathrm{~cm}$. Signed and dated (no. 33626).

the material bears the stamp of Lear's artistic idiom; in fact it is only in a small minority of the drawings -14 views of the Peloponnese $-{ }^{10}$ that we can recognise the precise draughtsmanship, richness of texture and sensitive, lyrical brushstrokes of colour which are a feature of his landscape drawings, together with the serial numbers added by the artist for his personal records and the plethora of notes with which he used to mark his travel sketches (figs 2, 3). The remaining 96 (dim. $17.5 \times 25 \mathrm{~cm}$ to $25 \times 35 \mathrm{~cm}$ ) will disappoint anyone familiar with Lear's drawings, since their composition ranges in quality from clumsy to amateurish (figs 4, 5), and their sparse washes of watercolour produce an effect far removed from the normal aesthetic quality of Lear's warm, unforced palette.

To this group of 'coloured-in' sketches must be added another eight watercolours from the recent donation of Maria Spentsa, which presumably belonged to her father, Damianos Kyriazis. Their dimensions are consistent with those mentioned above (paper, $25 \times 35 \mathrm{~cm}$ ), and they display tonal gradations which are at best crude and at worst unacceptable for a professional artist of the era (fig. 6). These additional sketches bring the number of 'problem' works to 104, and they include travel sketches mainly from the Peloponnese and Attica with hand-written dates covering the period from 7 March and 18 April 1849; many of these are numbered consecutively from 1 to 40 (March) and 5 to 22 (April), ${ }^{11}$ thus allowing us to reconstruct the six week tour in precise detail. All bear a signature in the form of a calligraphic monogram which can be read as E.L. or as F.L., since the strokes of the first initial merge into the second (figs 4-6). A study of comparable works which I have located in other collections ${ }^{12}$ shows that the dates and locations correspond exactly with those of the journey which Lear made through the Peloponnese, Attica and Mainland Greece in March and April 1849. ${ }^{13}$

Lear's travel sketches, a form of artistic diary, exemplify a working method ideally suited to the requirements of a conscientious artist-traveller who aimed at clear, 

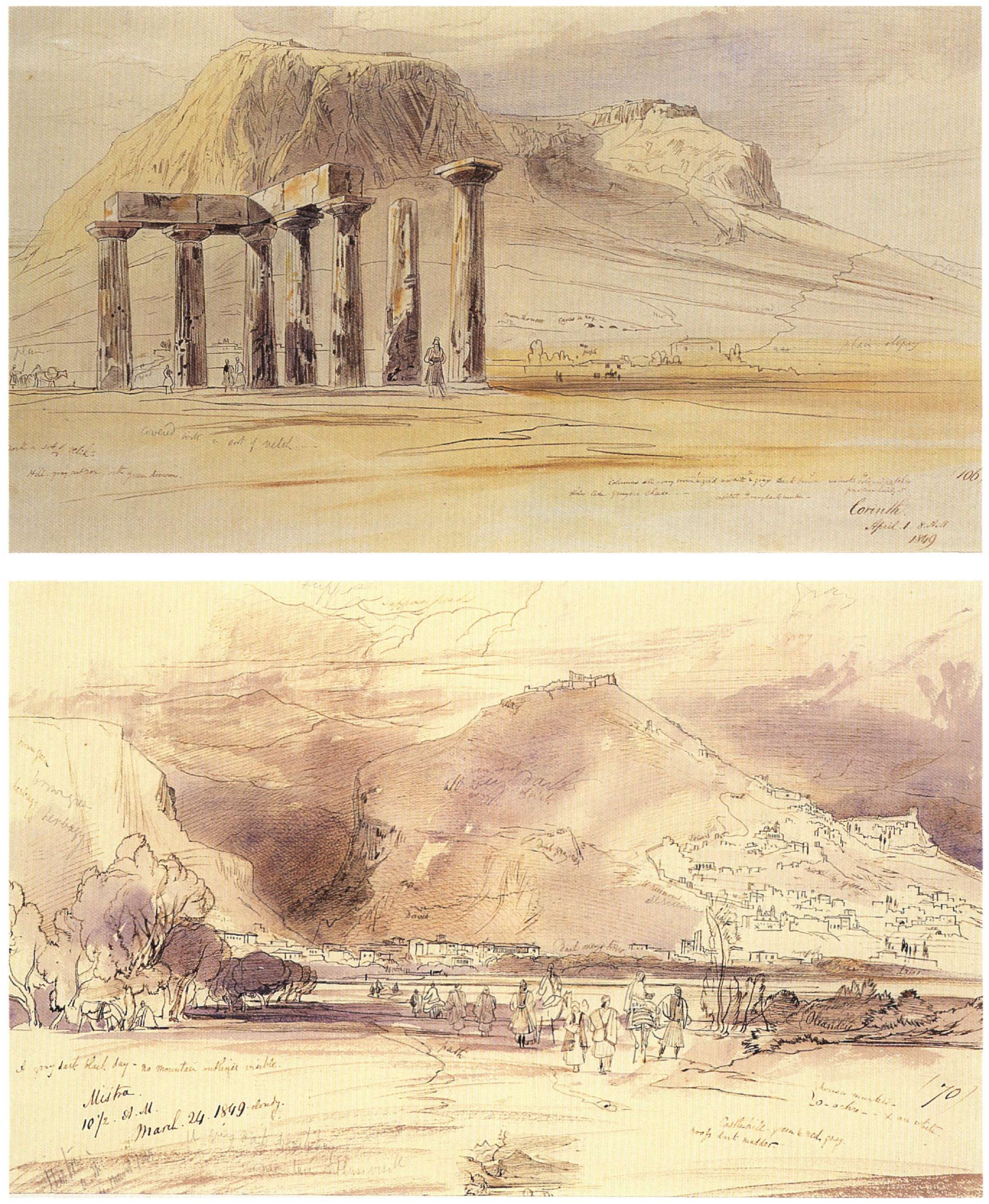

Fig. 2. E. Lear. View of ancient Corinth, 1849. Watercolour on paper, 29 x $51 \mathrm{~cm}$ (no. 24063).

Fig. 3. E. Lear. View of Mystras, 1849. Watercolour on paper, 26.5 x 41.5 cm, dated "24 March 1849" (no. 24062). 

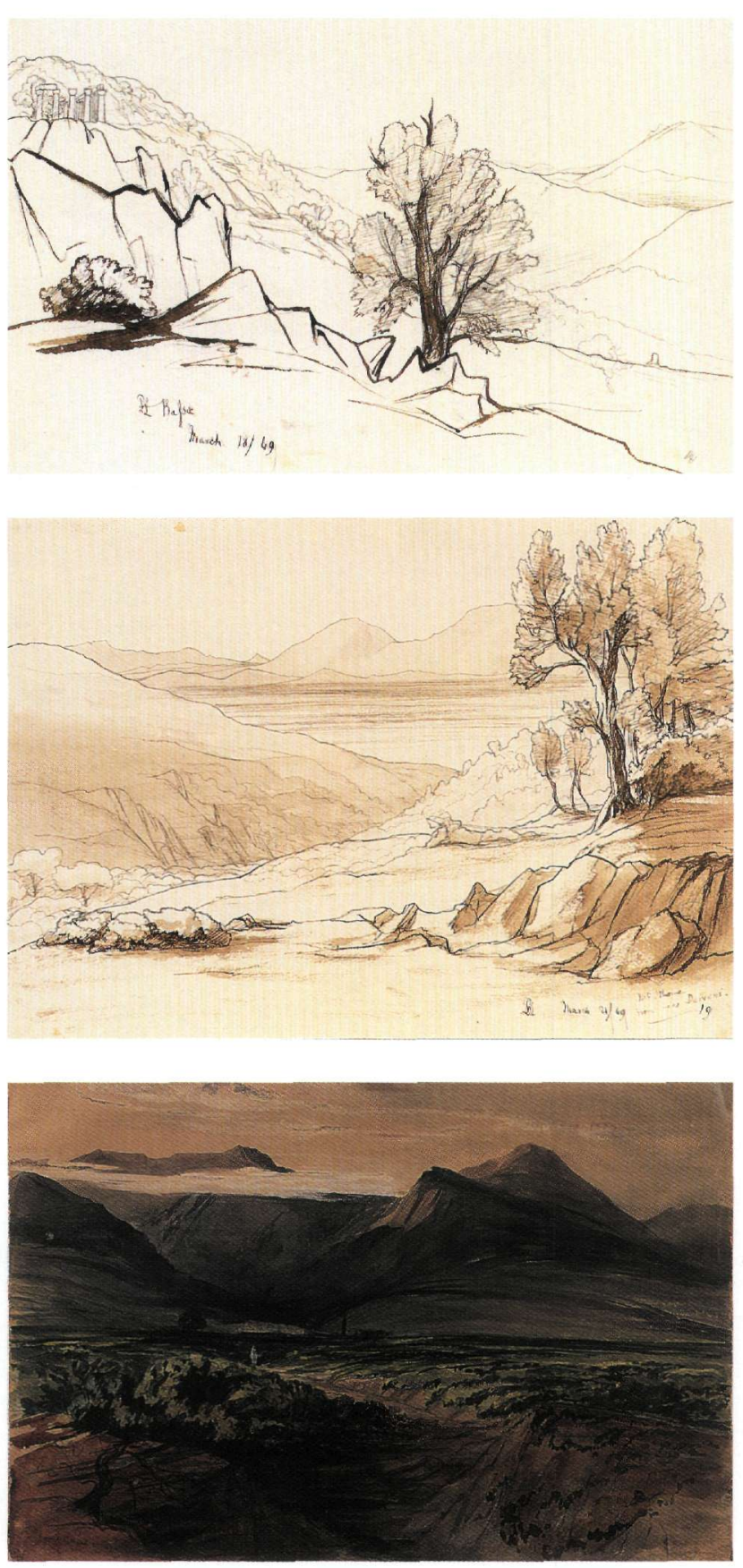

Fig. 4. F. Lushington, View of Bassae, 1849. Sketch, ink on paper, $17.5 \times 25 \mathrm{~cm}$, signed with monogram and dated

"March $18 / 49$ " (no. 24700).

Fig. 5. F. Lushington, Landscape towards Mt Ithome, 1849. Sketch, sepia on paper, $17.5 \times 25 \mathrm{~cm}$, signed with monogram and dated "March 21 / 49" (no. 24705).

Fig. 6. F. Lushington, Mountain landscape, 1849. Watercolour on paper, $25 \times 35 \mathrm{~cm}$, signed with monogram and dated "March 11/1849" (no. 38766). concise and reliable visual notes. In addition to the location, the artist also jotted down comments on the geographical features of the landscape, fauna and flora, ${ }^{14}$ and special characteristics of light and atmosphere. At the same time, he used a coded vocabulary to record resemblances to places which he had sketched in the past - "walls dashed with red ochre Amalfiwise" for example, and "pale Syracuse stone". These notes are often a direct expression of the artist's mood which the viewer is thus able to share, and his delightful comments recall the language of the famous Nonsense Rhymes. ${ }^{15}$

Lear's masterful reproduction of the Greek countryside and the accuracy of his draughtsmanship are exemplary -indeed, this is one of the features which gives his work as a Greek landscape artist its particular significance. For example, on a view of Mystras, he wrote: "Attention. A gray black dark day - no mountain outline visible" ${ }^{16}$ The extent of these notes varies, but the date and the serial number are seldom omitted. The original on-the-spot pencil drawing was followed by a second stage, the "penning out". This was the standard procedure for many artist-travellers, who needed to preserve the pencilled outlines which they had hurriedly drawn in the open air. Lear used pen and ink to trace over not only these lines, but also all his hand-written notes, and, as he says in his diary, penning out was an industrial process which could be completed several months after making the original drawing. ${ }^{17}$

From the typological point of view these 'problem' works belong with the travel sketches mentioned earlier -pencil drawings with the outlines and dates later inked in. Their draughtsmanship raises some queries, however. Admittedly, the general quality of Lear's travel sketches is uneven, since, painstaking artist that he was, he often made more than ten on-the-spot drawings. Yet his masterful handling of line and mass is never absent even in the most rapid sketches, such as the miniature illustrations which he often drew in the margin of the sheet as a first overall impression of the composition, the 'totality' as he called it (fig. 7).$^{18} \mathrm{~A}$ small number of the 'problem' works which display hasty but competent draughtsmanship resemble these miniatures stylistically and may be considered as rudimentary on-the-spot drawings in Lear's hand, but their incompetent colouring is far removed from the gifted artist's famously harmonious palette. And the presence of a signature in every item of the 


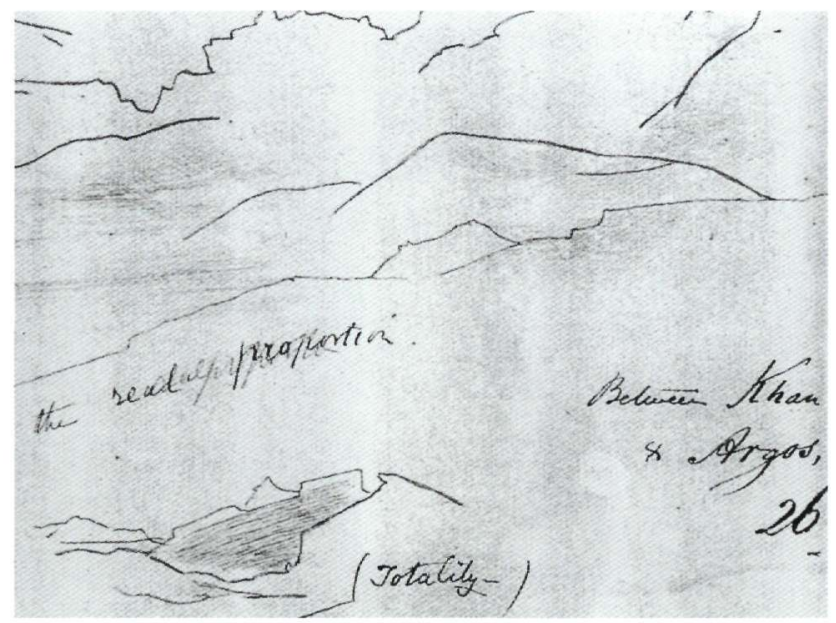

Fig. 7. E. Lear. Detail from View of Argos, 1849. Sketch, pencil and sepia on paper, $26 \times 43 \mathrm{~cm}$. Athens, Gennadius Library, no. 152.

group is particularly problematic; for Lear never signed such sketches, which were topographical working drawings, not intended for exhibition but kept in his studio as samples of his work to encourage potential clients to commission a landscape painting. Moreover the theory that the calligraphic monogram represents Lear's initials, E.L., will not hold water for two clear reasons: firstly the monogram which appears in Lear's completed works, both watercolours and oil paintings, has a different form, L.E. (fig. 8), and secondly this monogram is known to have been conceived by him in 1859, as he himself mentions in a letter dated July of that year. ${ }^{19}$

It follows that the first letter should be read not as ' $E$ ' but as 'F', and the person responsible for the sketches must have the initials F.L. The vital clue to deciphering the identity of the person behind these initials can only be discovered -with a touch of detective work- by examining the facts of the case: in this way we find the enigmatic combination of the initials F.L. with the mediocre quality of the works pointing us in the direction of an amateur draughtsman, Lear's travelling companion on this trip -his bosom friend, Franklin Lushington. A distinguished member of the legal profession in Victorian England ${ }^{20}$ and a cultivated hellenophile, Lushington (1825-1901) (fig. 9) was appointed judge to the Supreme Court of the Ionian Islands at Corfu in 1855 , and remained in this post for three years, during

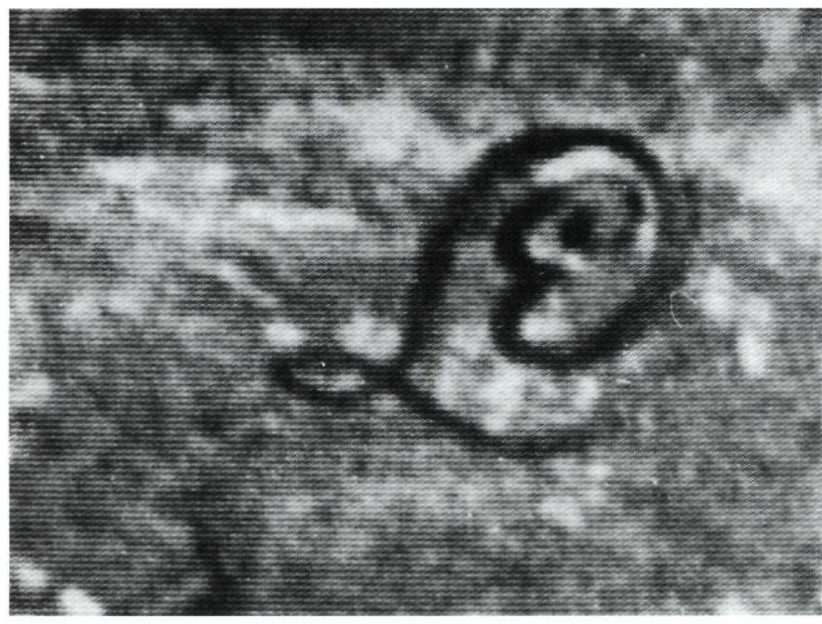

Fig. 8. Lear's monogram. Detail from View of Corfu, 1862. Oil on canvas. London, private collection.

the governorship of Sir John Young. ${ }^{21}$ In the summer of 1858 he returned to England to devote himself to a full-time legal career; he later married and Lear was godfather to his first child. It should be noted that the dates of Lear's first residence in Corfu coincide exactly with those of Lushington's term of office there: Lushington played a crucial role in Lear's private life, not merely as a friend of long-standing, but even more because Lear's repressed and unreciprocated homosexual feelings for the man who was thirteen years his junior were a continuing source of unhappiness to him. In his capacity as Lear's executor and heir to all his papers, Lushington regrettably destroyed all their correspondence and systematically censored his friend's diaries, removing whole pages and deleting paragraphs, as can be seen from Lear's thirty 'plundered' diaries, now in the Houghton Library at Harvard.

"I am about to set off for Greece. My companion is MrF. Lushington -the government secretary's brother at Malta, a very amiable and talented man - to travel with whom is a great advantage to me as well as pleasure", wrote Lear to his sister from Malta on 8 March 1849. He had just returned from a brief visit to North Africa, and was planning a second trip to Greece, which he had first visited the previous summer. The two companions disembarked at Patras on 7 March and after making the necessary arrangements began their exploration of the 


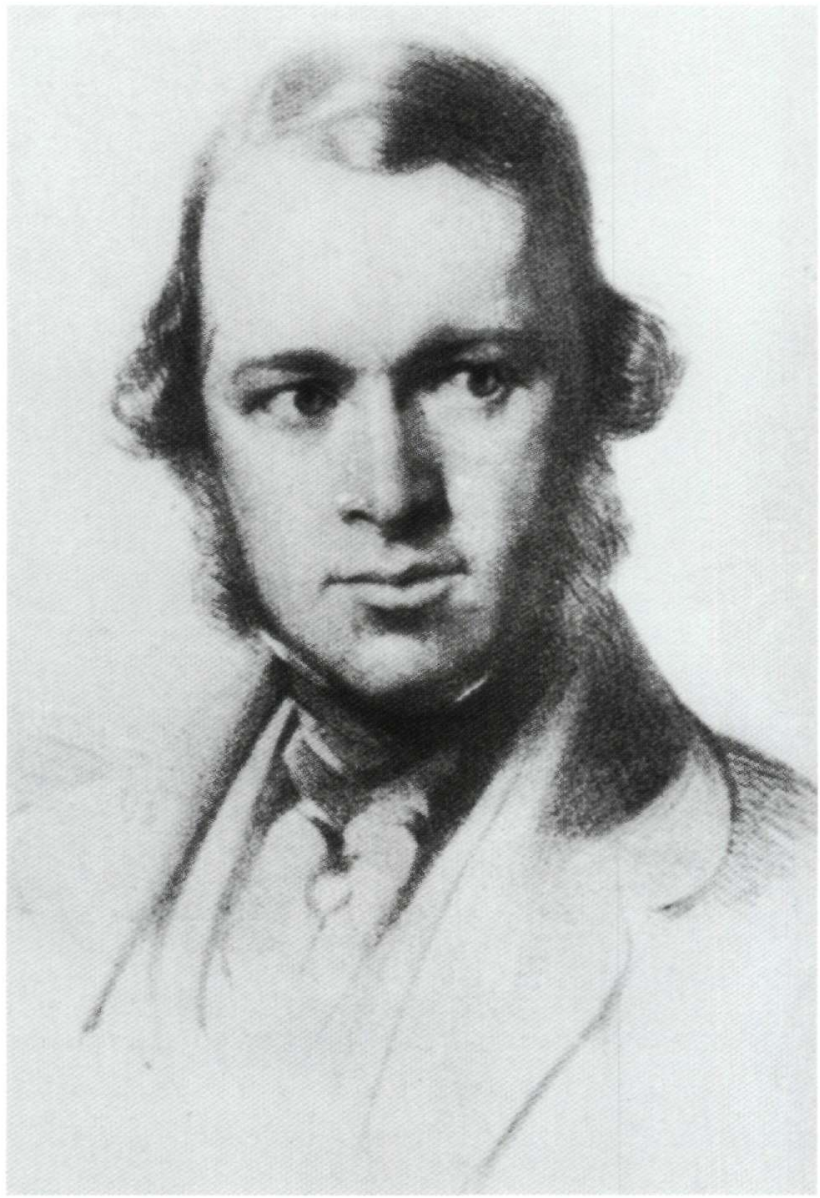

Fig. 9. F. Lushington, photograph.

Peloponnese two days afterwards. Six weeks later, on 21 April 1849, Lear wrote from Patras to his sister: "... the most delightful tour I have ever made. Everything has been so fortunate and pleasant that the time has gone by a great deal too quickly... Mr Lushington has been so constantly the most merry and kind travelling companion and I am very sorry he is obliged to return to England... Altogether I do not know when I have enjoyed myself more".

The fact that a young British lawyer in 1849 could display a certain talent as a draughtsman should cause no surprise, as drawing lessons were a regular part of the educational curriculum in upper-class Victorian England. We know that travellers were eager to exercise their artistic skills at a time when the sketchbook had not yet been superseded by the camera, and such amateurs played an important role in the history of British art, particularly of landscape painting. ${ }^{22}$ No doubt
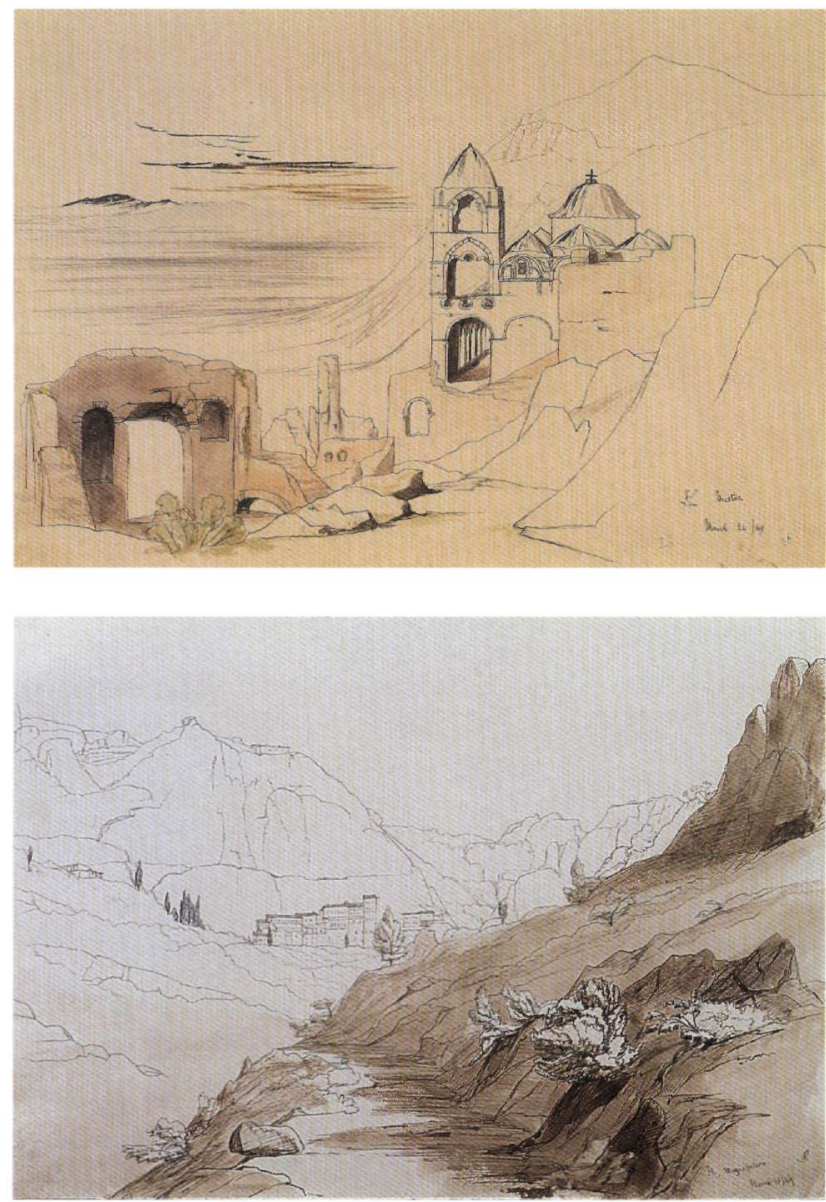

Fig. 10. F. Lushington, The Pantanassa, Mystras, 1849. Sketch, sepia and watercolour on paper, $25 \times 35 \mathrm{~cm}$, signed with monogram and dated "March 24/1849" (no. 24709).

Fig. 11. E. Lear, F. Lushington, Megaspelion, Kalavryta, 1849. Sketch, pencil and sepia on paper, $25 \times 35 \mathrm{~cm}$, signed with monogram and dated "March 10/1849" (no. 24685).

Lushington practised his drawing on the tour, taking full advantage of the presence of his artist companion, who in his turn was only too happy to give him advice. The Benaki's series of 'problem' sketches may therefore be viewed as the product of a close artistic collaboration between Lear and Lushington. Most of them would have been completed by Lushington under Lear's supervision (fig. 10), while the small group mentioned above, which display a superior compositional structure and a studied use of line (fig. 11), are likely to have been rough on-the-spot pencil sketches by Lear, who subsequently gave them to Lushington. We know that 


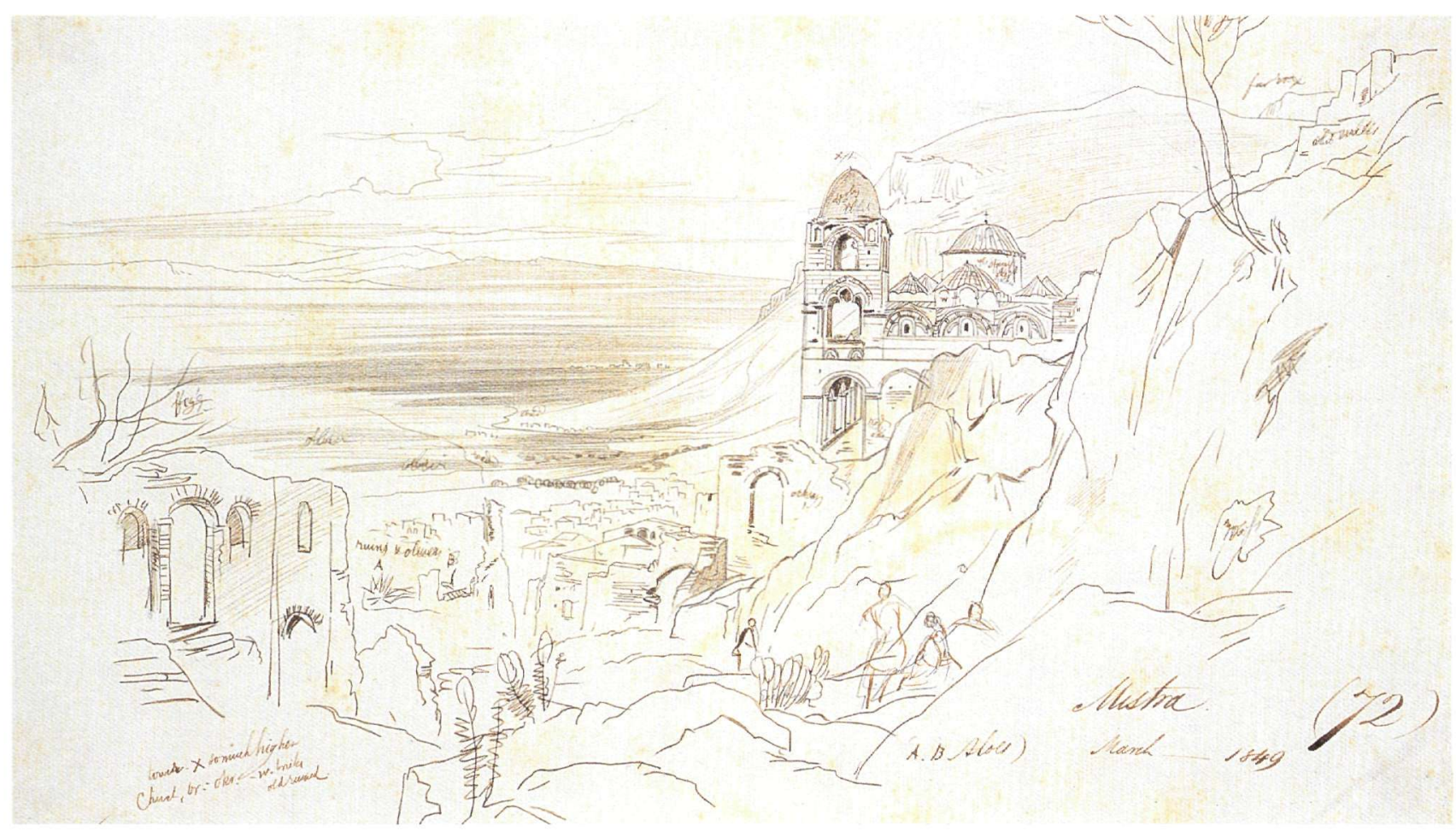

Fig. 12. E. Lear. The Pantanassa, Mystras, 1849. Sketch, sepia on paper, 24.5 x $41 \mathrm{~cm}$, annotated "Mistra, March 1849 " (no. 24785).

Lear, who often made more than one such drawing with minor variations (fig. 12), would on returning from his travels 'catalogue' his sketchbooks by numbering the pages; so assiduous was he in this regard that whenever had to give a drawing away, he would first make a copy of it. He presumably gave his companion some of the sketches made on their journey, and in fact one of the resulting watercolours, a view of Karytaina, contains a note in Lear's hand: "The original of this sketch is one of 6 given to F.L.". ${ }^{23}$ We may therefore speculate that at the end of the journey Lushington had in his possession a series of drawings comprising both his own work and sketches given to him by Lear, which he worked up "after the manner of Lear" -i.e. he elaborated, numbered, penned out and coloured them, before 'appropriating' all of them with his monogram "F.L.", which he perhaps made to resemble that of his friend. All this might well have been done with Lear's approval, in view of the general mood of euphoria which marked the journey. It should be noted that the works in the Kyriazis collection were bought in 1929, the year in which Lushington's daughters had put all their father's private papers up for sale. $^{24}$

There can be no doubt now that the Benaki Museum's Edward Lear collection comprises works by two artists, and this reassessment results in the following overall picture. The collection consists of a total of 182 works, of which 78 -views of Italy and Greece dated 1838-39, 1848-49 and 1850-63 respectively-are unquestionably the work of Lear. The remaining 104, dated March and April 1849, whose subjects are drawn from the Peloponnese and Attica, are attributable to Franklin Lushington. ${ }^{25}$

The Museum's Lear collection may not be impressive in theme or size. It is however unique in one respect: it is charged with the specific weight of a direct experience and echoes the immediacy of the artist's personal story, traits which no art historian should ever fail to detect within the area of artistic creation.

Fani-Maria Tsigakou curator of Paintings, Prints and Drawings Collection e-mail:tsigakou@benaki.gr 


\section{Notes}

* The Lear collection will be published as part of the catalogue raisonné of all the works in the Department of Paintings, Prints and Drawings, to be produced with the collaboration of specialists in the field.

1. Signed and dated 1854, $33 \times 53 \mathrm{~cm}$ (Benaki Museum no 33626).

2. In this article 'Greece' means the area within the country's present-day frontiers, unless otherwise stated. At the time of Lear's first visit in 1848 the kingdom of Greece did not yet include Thessaly, Epirus, Macedonia, Crete, the Ionian Islands and many of the other islands.

3. V. Noakes, Edward Lear: the Life of a Wanderer (London 1968).

4. M. Hardie, Watercolour Painting in Britain III (London 1968) 63-69.

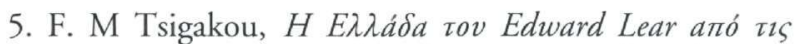

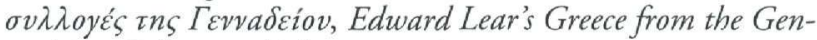
nadeion Collections (Athens 1997).

6. "The gleanings of a landscape painter" was his description in the Introduction. The book contains twenty lithotints, of which nine depict places in Greece: Yenidjé (Yiannitsa), Vodhena (Edessa), Ioannina, Nicopolis, Arta, Suli, Parga, Meteora and Tempe.

7. The total length of time Lear spent in Greece amounted to almost four years: April to December 1848, March to June 1849, December 1855 to August 1858 (with short breaks), the winter months of 1861 to 1864 , April 1866.

8. The album contains 20 lithotints and a title page with a vignette. The lithographic plates were prepared by Lear himself and printed by Day \& Son. They bear the words Edward Lear, delt. et lith and his monogram. The vignette on the title page is entitled View from "One Gun Battery" (i.e. Kanoni), Corfu. The titles of the main plates are: 1) View from above the village of Ascension (Analipsi), Corfu, 2) Mount San Salvador (Pantokrator), Corfu, 3) View from the orange gardens of Viro, Corfu, 4) View from the Benitsa road near Castouri, Corfu, 5) View from the hill of Santi Deka (Agioi Deka), Corfu, 6) Palaiokastritsa, Corfu, 7) Castel Sant'Angelo (Angelokastro), Corfu, 8) The villages of Lefchimo, Corfu, 9) View from the fort, Santa Maura (Lefkada), 10) Amaxichi and the fort, Santa Maura, 11) Capo Ducato, or Sappho's Leap, Santa Maura, 12) Argostoli and the Black Mountain (Mavrovouni), Cephalonia, 13) Walls of ancient Samos, Cephalonia, 14) Town and fortress of Assos, Cephalonia, 15) View from the castle hill looking towards Monte Scopo, Zante (Zakynthos), 16) View from Monte Scopo, Zante, 17) View from the village of Galaro, Zante, 18) Town and harbour of Gaio, Paxo, 19) Harbour and town of Vathy, Ithaca, 20) The castle and town of Cerigo and port of Kapsali, Cerigo (Kythira).

9. Cf. F-M. Tsigakou, The Rediscovery of Greece (London

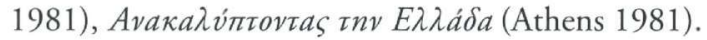

10. The 14 views are as follows: 1) Mt Ithome, 20 March $1849,28.5 \times 52 \mathrm{~cm}$ (no. 24775), 2) Messene, 20 March 1849 , 25 x $42 \mathrm{~cm}$ (no. 24776), 3) Mavromati, 20 March 1849, 13.5 x $22 \mathrm{~cm}$ (no. 24777), 4) Sparta, 23 March 1849, 26.5 x 40.5 cm (no 24778), 5) Sparta, 23 March 1849, 25 x $41.5 \mathrm{~cm}$ (no. 24779), 6) Mystras, 24 March 1849, 23 x $15 \mathrm{~cm}$ (no. 24780), 7) Landscape near Mystras, $15.5 \times 23 \mathrm{~cm}$ (no. 24781), 8) Landscape near Sparta, $15.5 \times 23 \mathrm{~cm}$ (no. 24782), 9) General view of Mystras, 15/24 March 1849, $21 \times 32 \mathrm{~cm}$ (no. 24783), 10) Mystras, the Palace, 24 March 1849, $15.5 \times 23 \mathrm{~cm}$ (no. 24784), 11) Mystras, the Pantanassa, March 1849, $24.5 \times 41$ cm (no. 24785), 12) View of Mystras, 24 March 1849, 26.5 x $41.5 \mathrm{~cm}$ (no. 24062), 13) Sparta, 23 March 1849, 31 x 51 cm (no. 24061), 14) View of Argos, 27 March 1849, $22.5 \mathrm{x}$ $35.5 \mathrm{~cm}$ (no. 24064).

11. The inventory numbers are: 24679-24728, 24773, 38504-38506, 38764-38766 (57 works), dated 7-31 March 1849; 24729-24741, 24743-24762, 244764-24773, 30311, 36367, 38509, 38733 ( 47 works), dated 1-17 April 1849.

12. The most important collection of Lear's works and manuscripts is in the Houghton Library at Harvard. Apart from the valuable collection of 202 works in the Gennadius Library, most of the works with Greek subjects are in private hands in Greece and abroad.

13. He landed at Patras on 9 March 1849, toured the Peloponnese and on 1 April was in Corinth en route for Athens, where he stayed for 6 days (3-9 April), visiting Sounion and Aigina. On 10 April he set out for Patras via Thebes, Livadia, Chaironeia, Arachova, Delphi, Salona and Naupactos, from where he crossed to Patras on 21 April. Lear's journal of his travels in Greece in 1848 and 1849 is preserved in a manuscript which was edited by his travelling companion Charles Marcus Church, whose descendants left it to Westminster School.

14. Lear was especially well suited to appreciate the Greek flora, as he was a distinguished illustrator of natural history and zoology books, e.g. The Gardens and Menagerie of the Zoological Society Delineated (London 1831), The Birds of Europe (London 1837).

15. In his view of Corinth (no. 24063) he describes the colour of the columns of the temple as "columns all very brown and gold-smoke-coloured patches- holes like gruyère cheese" while in a view of Salamis (no 24795) he calls the island "Sally Miss". Lear was celebrated for his "nonsense limericks", poems which tell a nonsensical story in five lines, using the rhyme scheme a,a,b,b,a: the limerick became a recognised form of verse after Lear's poems were published in 1846 under the title $A$ Book of Nonsense.

\section{No. 24062.}

17. Sometimes Lear delegated the penning out to an assistant such as Franklin Underhill, as he noted on a work in the Gennadius Library collection, Tsigakou (n. 5) 30. 
18. "When we came to a good subject, Lear would sit down, and taking his block..., would lift his spectacles, and gaze for several minutes at the scene through a monocular glass he always carried; then, laying down the glass, and adjusting his spectacles, he would put on paper the view before us, mountain range, villages and foreground, with a rapidity and accuracy that inspired me with awestruck admiration", Strachey, Later letters 23 (Preface). The 'totality' was this preliminary outline sketch of the composition, based on his observation through the glass.

19. "My new assygram", as he described it in a letter dated July 1859 to his friend Chichester Fortescue. Lear's correspondence, edited by Lady Strachey, was published as Letters of Edward Lear (London 1907) and Later letters of Edward Lear (London 1911). Most of the biographical information we have about Lear comes from his almost daily correspondence to his sister Ann and his friends. Lear was a letter-writer of legendary prolixity and he would write up to eight letters a day. As he himself said: "every created human being capable of writing since the invention of letters must have written to me with a few exceptions perhaps, such as the prophet Ezekiel, Mary Queen of Scots, and the Venerable Bede".

20. Lushington's family had close ties with that of Alfred Lord Tennyson, the Poet Laureate, for whom Lear had a deep admiration. In 1851, after Lear had sent him a copy of his Albanian journal, Tennyson responded by composing a poem entitled To E.L. on his Travels in Greece.
21. Sir John Young was Lord High Commissioner of the Ionian Islands from 1855 to 1858 , when he resigned after criticism from the government of his liberal views. Lushington resigned his office as judge in Corfu at the same time as Young.

22. Cf. M. Hardie, Watercolour Painting in Britain III (London 1968) 245-67.

23. Karytena. Watercolour on paper, $34 \times 51.5 \mathrm{~cm}$. Athens, Gennadius Library, no 151.

24. All Lear's papers which were in the possession of the Lushington family were auctioned at Sotheby's and Hodgson's in 1929. The majority were bought afterwards by two American collectors, W. Osgood Field and P. Hofer, who donated them to the Houghton Library at Harvard in 1942. In 1929 Joannes Gennadius negotiated with the dealers Craxton and Bernard for the acquisition by the American School of Classical Studies, Athens of the works now in the Gennadius Library; D. Kyriazis and, probably, A. Benakis acquired their works from the same source.

25. I first mentioned the 'problem' series of drawings in a paper entitled A 'First-Chatter-Nonsense-Making' artist and a Grecophile lawyer in the Morea of 1849, which I presented in 1994 as part of the symposium Travellers and Officers in the Peloponnese, organised in honour of Sir Stephen Runciman by the Monemvasia Society.

\section{ФANH-MAPIA T $\Sigma$ IГKAKOY}

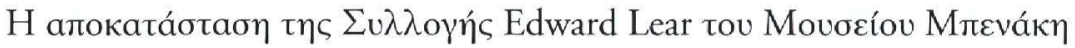

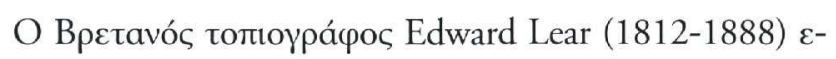

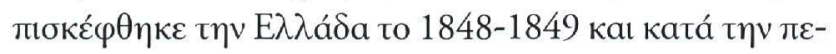

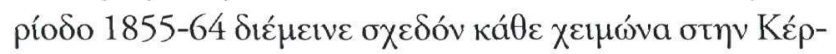

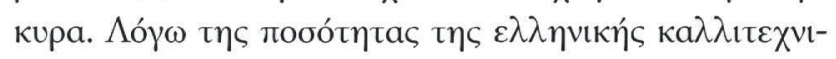

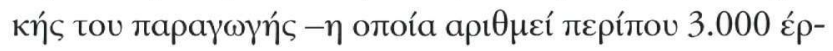

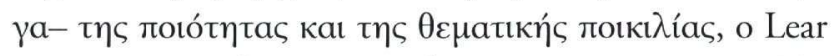

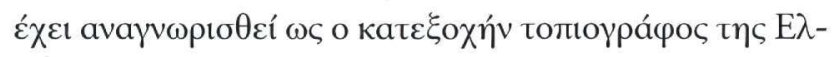
$\lambda$ ádac tou 19 ov aı́́va.

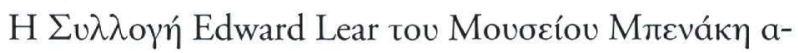

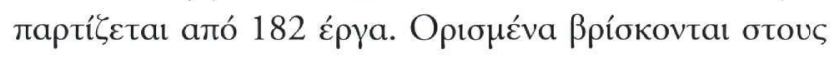

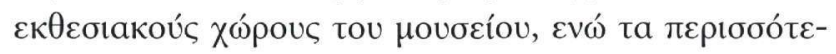

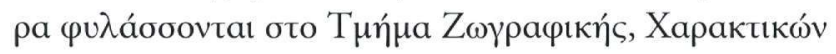

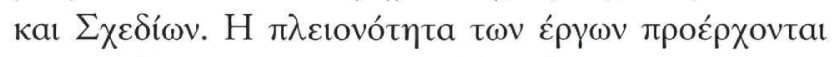

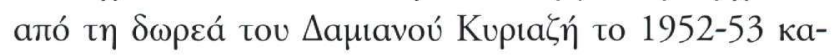

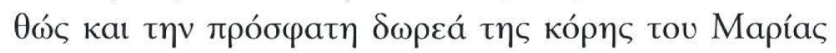

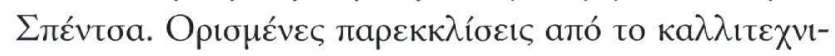

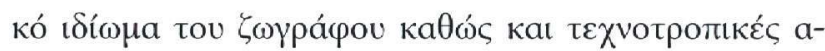

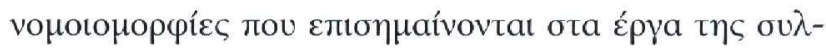

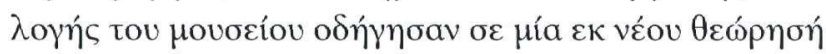

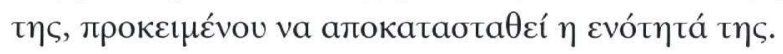

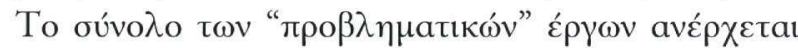

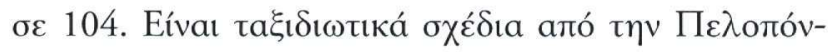

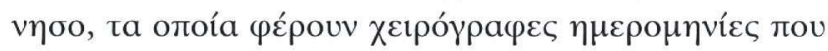

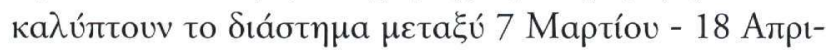

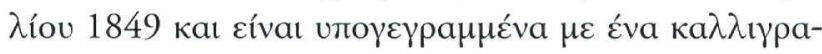

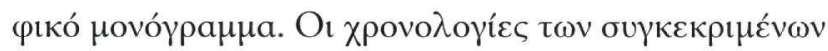

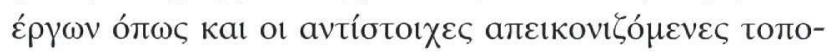

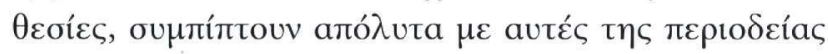

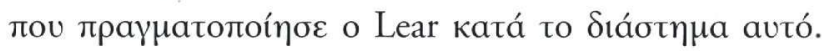

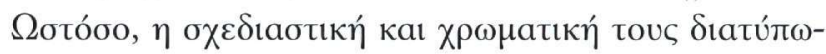

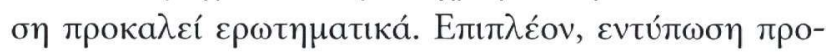

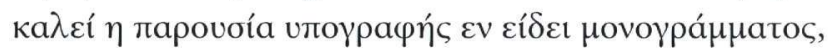




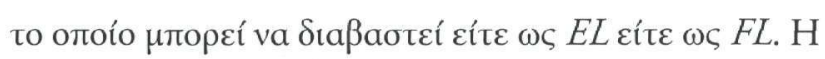

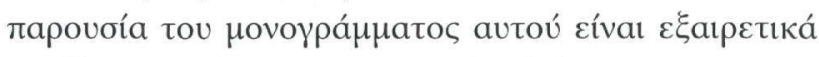

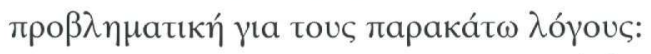

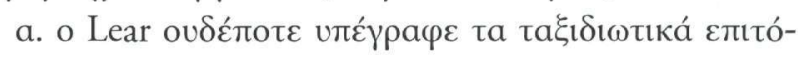

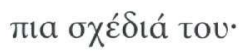

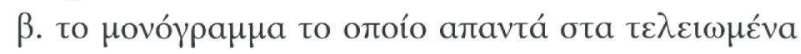

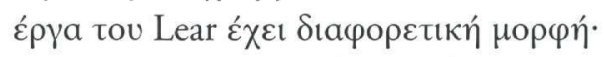

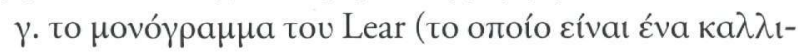

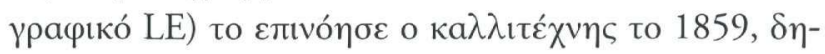

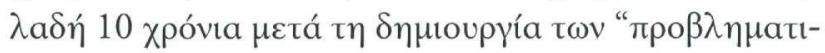

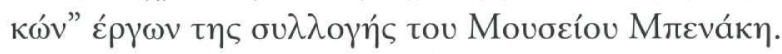

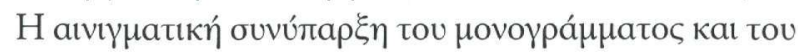

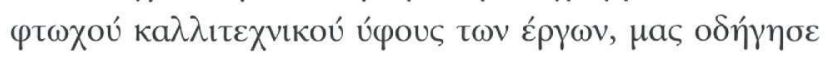

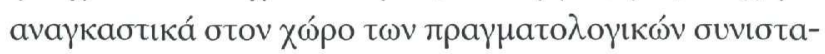

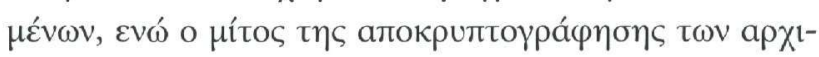

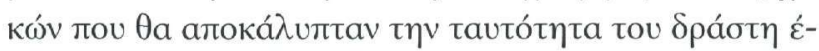

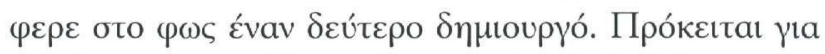

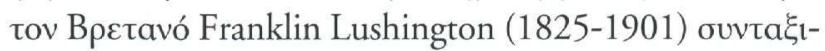

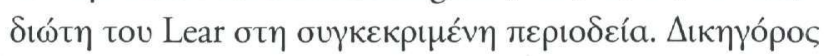

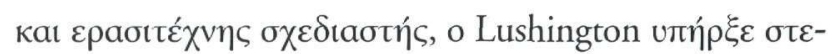

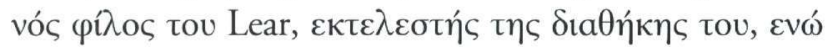

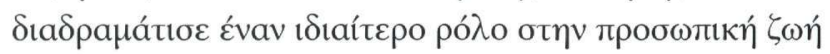

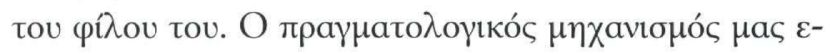

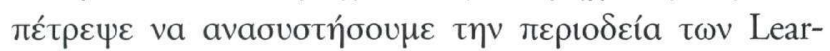

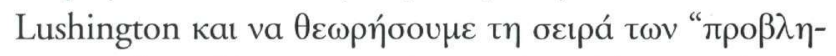

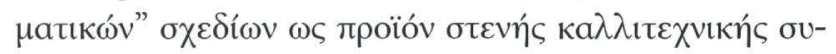

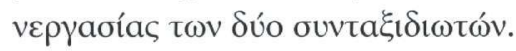

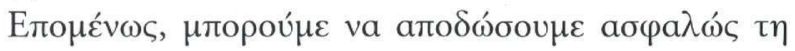

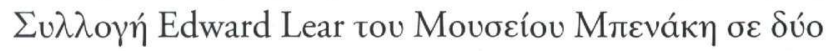

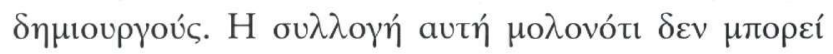

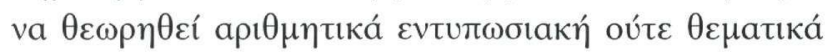

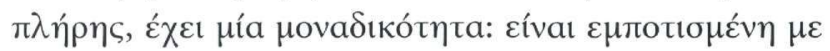

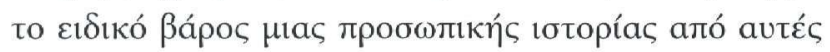

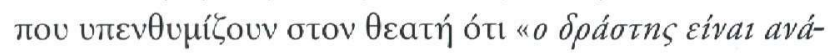

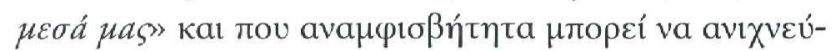

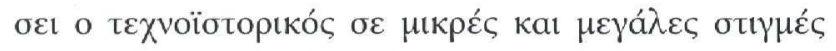

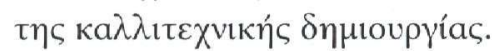

